\title{
Role of Negative Suction Drain in Subcutaneous Plane in Reducing Laprotomy Wound Infection
}

\author{
Khan A. $Q^{1}$, Mahesh Kodalkar ${ }^{1}$ \\ ${ }^{1,2}$ Department of General Surgery, MGM Medical College \& Hospital, N-6, Cidco, Aurangabad, Maharashtra, India
}

\begin{abstract}
Surgical site infection is one of the most common postoperative complications. Surgical site infection rate higher in abdominal surgery. Even after thorough peritoneal irrigation with normal saline, the incidence of wound infection is high. The authors have studied the effectiveness of putting a negative suction drain (Romo-Vac Drain) in the subcutaneous space in prevention of wound infection and wound dehiscence in patients of midline laparotomy. The patients were divided in two groups; group A, where a negative suction drain was put, and Group B, where no negative suction drain was put in the subcutaneous space at the time of closure of the abdomen after laparotomy. In group A, incidence of surgical site infection, seroma formation, wound dehiscence and hospital stay was remarkably lower as compared to Group B, where no drain was put in subcutaneous space.
\end{abstract}

Keywords: Surgical site infection, Romo-Vac Drain, laparotomy, subcutaneous space.

\section{Introduction}

Surgical site infection is one of the most common postoperative complications, occurring in at least $5 \%$ of all patients undergoing surgery and $30-40 \%$ of patients undergoing abdominal surgery, depending on the level of contamination. ${ }^{1}$ Development of a surgical site infection has a large impact on mortality and morbidity as well as healthcare costs, patient inconvenience and dissatisfaction. ${ }^{2,3}$ Infectious complications are the main causes of postoperative morbidity in abdominal surgery Wound infection: the most common form is superficial wound infection occurring within the first week of surgery ${ }^{4}$.Seroma formation is one of the complication after abdominal surgery. Seroma can lead to wound related complication, such as Abscess formation, Calcification of the seroma, Poor cosmetic result; unsatisfactory appearance of a surgical scar. Abdominal wound dehiscence is one of the complication after abdominal surgery, wound dehiscence is the parting of the layers of a surgical wound. Either the surface layers separate (wound gap) or the whole wound splits open, primary cause of wound dehiscence is infection and seroma formation, wound dehiscence has only wound gap small in size treated with regular dressing and heal itself. when wound dehiscence is deep use regular dressing, debridement of infected part and after granulation tissue formation secondary suturing done ${ }^{5}$. Negative suction in subcutaneous space has been shown to reduce the incidence of infection by evacuation of infected content, evacuation of collected seroma in subcutaneous space. Negative suction improves the healing capacity of the wound by reducing its bacterial load. ${ }^{6,7,8}$

Negative pressure providing a moist and protected environment, reducing peripheral oedema around the wound, stimulating circulation to the wound bed, decreasing bacterial colonization, increasing the rate of granulation tissue formation and epithelisation.

\section{Objective}

The objective of this study was to evaluate and compare the wound infection, seroma formation, wound dehiscence with subcutaneous negative suction drain and without subcutaneous drain in post laparotomy surgery.

\section{Material and Methods}

\subsection{Type of Study}

This is comparative and randomized study conducted in two groups.

\subsection{Study Centre}

MGM MEDICAL COLLEGE AND HOSPITAL AURANGABAD from $1^{\text {st }}$ September 2013 to $1^{\text {st }}$ October 2015

3.3 In this study all patients underwent radiological investigation like USG ABDOMEN and $\mathrm{X}$ ray abdomen standing, CT abdomen is not mandatory.

3.4 Use of appropriate antibiotic in each patient as required on general condition of patient.

3.5 Patients are randomly selected and divided in to two groups.

In group A: - 50 cases in which romovac negative suction drain (in fig1) is placed in subcutaneous plane at the time of closure of abdomen in laparotomy surgery

In group B: - 50 cases in which no negative suction drain is placed in subcutaneous space at the time of closure of abdomen in laparotomy surgery.

3.6 Closure of abdominal wound with same technique in all cases, (rectus sheath closed with ethilon loop no.1 subcutaneous closed with vicryl 2.0 and skin closed with ethilon 3.0.)

3.7 Use of appropriate romovac negative suction drain with in group A patient.

3.8 Daily observation of surgical site and drain quantity and content was done in post operatively. 


\section{International Journal of Science and Research (IJSR) \\ ISSN (Online): 2319-7064}

Index Copernicus Value (2013): 6.14 | Impact Factor (2014): 5.611

3.9 The drain was removed on post-operative day 3 or collection in drain was nil.

3.10 All patients were studied postoperatively in terms of surgical site infection, seroma formation and wound dehiscence.

3.11 The result from both the groups compared and analysed.

\section{Inclusion Criteria}

Age group between 16 years to 75 years' patients.

All laparotomy with midline incision performed at MGM MEDICAL COLLEGE AND HOSPITAL AURANGABAD.

\section{Exclusion Criteria}

Age $<16$ year and $>75$ year patients

Accidental removal of drain

All immunocompromised patients

Patients with co morbidities like diabetics, hypertension, bronchial asthma and tuberculosis

Patients who were in shock at the time of presentation.

Death of patient in postoperative period due to systemic cause.

Patients required ileostomy for surgical reasons. patients suffering from malignancies.

\section{Results}

The data collected in the present study is analyzed statistically by computing the descriptive statistics viz., Mean, SD, and percentages. The data is presented in the form of tables and graphs. The measures of association between the qualitative variables are assessed using chisquare test. The inference is considered statistically significant whenever $\mathrm{p} \leq 0.05$.

\subsection{Post-Operative Wound infection}

The total number of wound infected during post-operative period for Group A it is $12 \%$ and for Group-B it is $30 \%$, after statistical analysis it is found that the post-operative wound infection is significant Chi-square value 4.88, $\mathrm{P}=0.027$.

Table 1: Distribution of patients according to

Table 1: Infection in Groups:

\begin{tabular}{|c|c|c|c|c|c|c|}
\hline Infection & Grou & $\mathrm{A}$ & Group & & Chi- & p-value \\
\hline & $\begin{array}{l}\text { No. of } \\
\text { Patients }\end{array}$ & $\%$ & $\begin{array}{l}\text { No. of } \\
\text { Patients }\end{array}$ & $\%$ & $\begin{array}{c}\text { square } \\
\text { test }\end{array}$ & \multirow{4}{*}{$\begin{array}{c}\mathrm{P}=0.027 \\
\mathrm{~S}\end{array}$} \\
\hline YES & 06 & 12.0 & 15 & 30.0 & \multirow{3}{*}{4.88} & \\
\hline NO & 44 & 88.0 & 35 & 70.0 & & \\
\hline Total & 50 & 100 & 50 & 100 & & \\
\hline
\end{tabular}

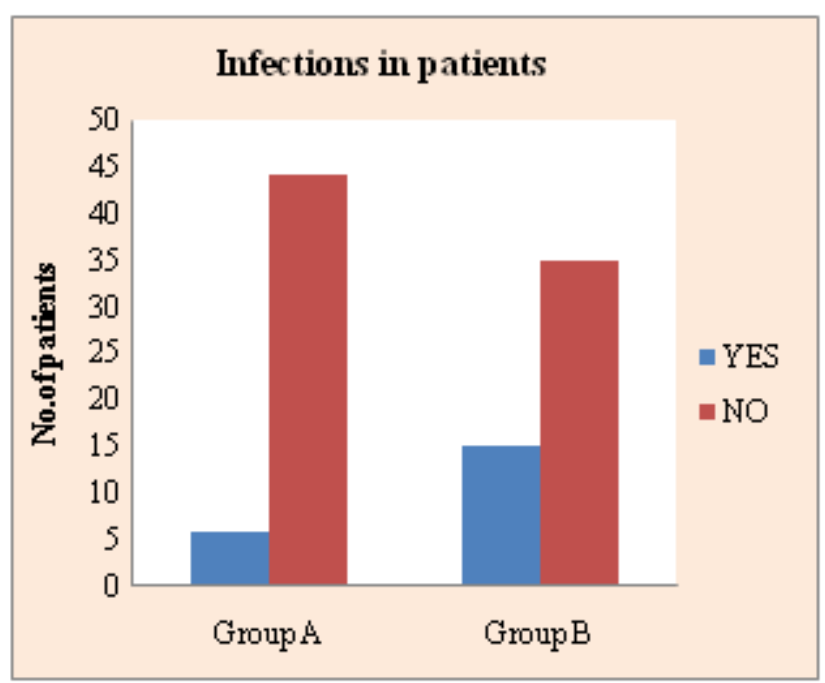

\subsection{Post-Operative Wound Seroma Formation}

The total number of seroma in wound during post-operative period for group A it is $16 \%$ and for group B it is $42 \%$, after statistical analysis it is found that the post-operative seroma in wound is significant chi-square value $8.53, \mathrm{P}=0.001$.

Table 2 can be depicted graphically as shown below

Table 2: Distribution of patients according to SEROMA in Groups:

\begin{tabular}{|c|c|c|c|c|c|c|}
\hline seroma & \multicolumn{2}{|c|}{ Group A } & \multicolumn{2}{c|}{ Group B } & Chi-sq. & p-value \\
\cline { 2 - 5 } & $\begin{array}{c}\text { No. of } \\
\text { Pats. }\end{array}$ & $\%$ & $\begin{array}{c}\text { No. of } \\
\text { Pats. }\end{array}$ & $\%$ & & \\
\hline YES & 08 & 16.0 & 21 & 42.0 & 8.53 & $\mathrm{P}=0.001$ \\
\hline NO & 42 & 84.0 & 29 & 68.0 & & \\
\hline Total & 50 & 100 & 50 & 100 & & \\
\hline
\end{tabular}

\subsection{Post-Operative Wound dehiscence}

The total number of wound dehiscence in wound during post-operative period for group A it is $14 \%$ and for group B it is $42 \%$, after statistical analysis it is found that the postoperative wound dehiscence in wound is significant chisquare value $9.72, \mathrm{P}=0.002$.

Table 3 can be depicted graphically as shown below

Table 3: Distribution of patients according to WOUND DEHISCENCE in Groups:

\begin{tabular}{|c|c|c|c|c|c|c|}
\hline $\begin{array}{c}\text { Wound } \\
\text { D. }\end{array}$ & \multicolumn{2}{|c|}{ Group A } & \multicolumn{2}{c|}{ Group B } & Chi- & p-value \\
\cline { 2 - 5 } & $\begin{array}{c}\text { No. of } \\
\text { Patients }\end{array}$ & $\%$ & $\begin{array}{c}\text { No. of } \\
\text { Pats. }\end{array}$ & $\%$ & sq. test & \\
\hline YES & 07 & 14.0 & 21 & 42.0 & \multirow{2}{*}{9.72} & $\begin{array}{c}\mathrm{P}=0.002 \\
\mathrm{~S}\end{array}$ \\
\hline NO & 43 & 86.0 & 29 & 68.0 & \\
\hline Total & 50 & 100 & 50 & 100 & & \\
\hline
\end{tabular}




\section{International Journal of Science and Research (IJSR) \\ ISSN (Online): 2319-7064}

Index Copernicus Value (2013): 6.14 | Impact Factor (2014): 5.611

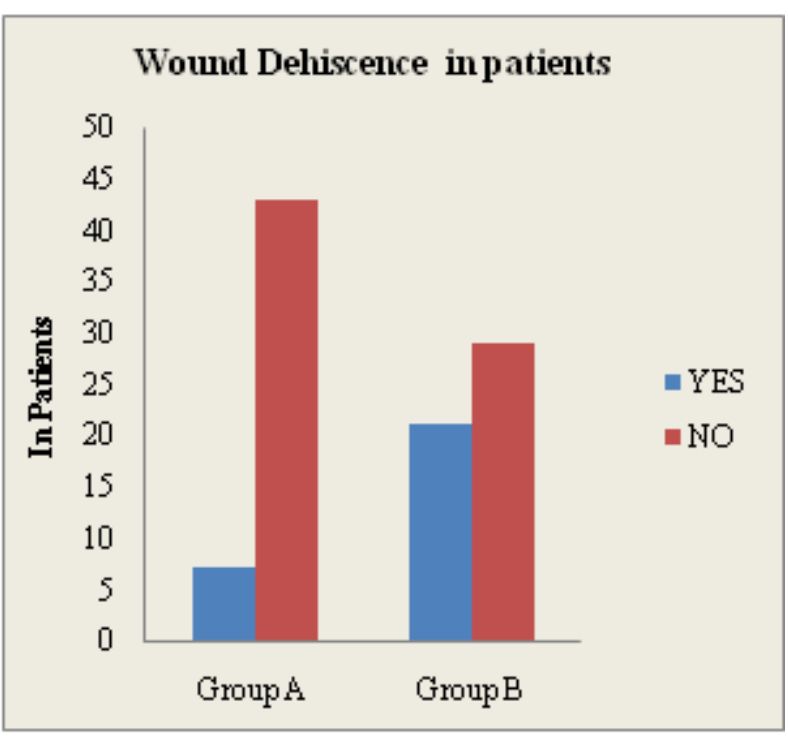

\section{Discussion}

Surgical site infection, seroma formation, and wound dehiscence is the most common complication in post laparotomy surgery. Development of a surgical site infection has a large impact on mortality and morbidity as well as healthcare costs, patient inconvenience and dissatisfaction. Infectious complications are the main causes of postoperative morbidity in abdominal surgery Wound infection: the most common form is superficial wound infection occurring within the first week of surgery. The use of negative suction drain in subcutaneous plane has been shown to reduce the incidence of surgical site infection, seroma formation, and wound dehiscence.

Yagnesh vaghani et.al ${ }^{10}$ study shows, surgical site infection rate was $25 \%$ in study group and $57.7 \%$ in control group. Another study was done by by Takaaki Fujii et.al at Department of General Surgical Science, Graduate School of Medicine, Gunma University japan ${ }^{11}$. in this study surgical site infection rate was $14.3 \%$ in study group, and $38 \%$ in control group.

In our study surgical site infection is $12 \%$ in study group and $30 \%$ in control group shows significant differences between two groups and also low as compare to Yagnesh vaghani et.al and Takaaki Fujii et.al study.

Nisar ahmad et.al study shows Seroma formation in surgical wound after laparotomy surgery was $16.74 \%$ in study group in which negative suction drain placed in subcutaneous plane and $72 \%$ in control group in which no drain use ${ }^{12}$. Ramsey et.al ${ }^{13}$ study from April 2001 to 2004 shows that seroma formation in surgical wound $10.6 \%$ in control group and $9.8 \%$ in study group

In our study seroma formation in study group is $16 \%$ and in control group is $42 \%$ shows significant between two groups. Ramsey et.al ${ }^{13}$ study shows that wound dehiscence in study group was $21.8 \%$ and in control group was $15.3 \%$ which is not significant in this study

In our study wound dehiscence in study group is $14 \%$ and in control group is $42 \%$ which show significant in two groups.

\section{Conclusion}

The results from the present study show that use of negative suction drain in subcutaneous plane during midline incision laparotomy surgery, reduces the incidence of postoperative surgical site of infection, seroma formation, wound dehiscence

\section{Reference}

[1] Bruce J, Russell EM, Millinson J, Krukowksi ZH. The measurement and monitoring of surgical adverse events. Health Tech Assess2001;5:1-194

[2] Wilson AP, Gibbons C, Reeves BC, Hodgson B, Liu M, Plummer D, et al. Surgical wound infection as a performance indicator: agreement of common definitions of wound infection in 4773 patients. BMJ2004;329:720-4

[3] Scott RD II. The direct medical costs of healthcareassociated infections in U.S. hospitals and the benefits of prevention. 2009

[4] Kujath P et al; Complicated skin, skin structure and soft tissue infections - are we threatened by multi-resistant pathogens?, European Journal of Medical Research 2010 15:544-553

[5] Van Ramshorst GH, Niouwen huiren J, Hop WC, Boom J et al. Abdominal Wound Dehiscence in Adults: Development and Validation of a Risk Model. World J Surg. 2010 Jan; 34(1): 20-27.

[6] Sadoshima J, Izumo S. Mechanical stretch rapidly activates multiple signal transduction pathways in cardiac myocytes: potential involvement of an autocrine/poracrine mechanism. EMBO J; 1993; 12: 1681-92.

[7] Vandenburgh $\mathrm{HH}$ : Mechanical forces and their second messengers in stimulating cell growth in vitro. Am J Physiol; 1992; 262: R350-55.

[8] Wirtz HR, Dobbs LG: Calcium mobilization and exocytosis after one mechanical stretch of lung epithelial cells. Science. 990; $250: 266-9$.

[9] Subramonia S, Pankhurst S, Rowlands BJ, Lobo $\mathrm{DN}$ :Vacuum assisted closure of postoperative abdominal wounds: a prospective study. World J Surg 2009; 33 : 93137.

[10] Yagnesh Vaghani, Jeeten Chaudhari, Sudhir Navadiya. A study of subcutaneous negative pressure closure versus simple closure in laparotomy wound of Ileal perforation. International Journal of Medical Science and Public Health 2014; 3(1) : 24-26.

[11] Takaaki Fujii , Yuichi Tabe, Reina , Satoru Yamaguchi, Soichi Tsutsumi,et.al. effect of subcutaneous drain fpr prevention of incisional SSI in high risk patients under going colorectal disease . International journal of colorectal surgery in September 2011, vol. 26 pp. 1151-1155

[12] Takayuki Asao, Hiroyuki Kuwano. Effects of subcutaneous drain for the prevention of incisional SSI in high risk patients undergoing colorectal disease.International Journal of Colorectal Surgery in Sept. 2011; Vol.26 : pp.1151-1155.

[13] Ramsey PS, White AM, Guinn DA, Lu GC, Ramin SM, Davies JK, Neely CL, Newby C, Fonseca L, Case AS, Kaslow RA, Kirby RS, Rouse DJ, Hauth JC. Subcutaneous tissue reapproximation, alone or in combination with drain, in obese women undergoing cesareandelivery. Obstet Gynecol. 2005 May; 105 967-73. 